\title{
Ethnomathematical paths to Financial Educacion: analysing cultural traits of Deaf students
}

\author{
Rodrigo Carlos Pinheiro \\ Milton Rosa
}

\begin{abstract}
The results obtained from research look at the cultural traits produced by Deaf students concerning the development of their financial education are in accordance to the perspective of the Ethnomathematics Program. In this article, the authors outline the participants' profile; and provide a brief description of grounded theory that forms the methodological design used to conduct this study by using specific coding procedures. The authors also emphasize the relation between ethnomathematics and deaf culture through the use of jargon and procedures used by Deaf students in the study of mathematical content related to Financial Education. We also present a diversity of ways of signing the same mathematical content in Brazilian Sign Language (Libras), as well the communicative differences that arise due to the use of these sign variations. The results obtained in this study show that ethnomathematics contributed to the understanding and awareness of the characteristics of Deaf Culture and its relations to school mathematics. Another contribution is that ethnomathematics and its pedagogical action acquired a relevant status in the elaboration of a mathematical curriculum and in the development of financial education for Deaf students.
\end{abstract}

Keywords: Deaf Students. Deaf Culture. Ethnomathematics. Brazilian Sign Language. Financial Education.

\section{Rutas etnomatemáticas hacia la Educación Financiera: análisis de \\ Rodrigo Carlos Pinheiro los rasgos culturales de los estudiantes Sordos}

Master's Degree in Mathematics Education, from the Universidade Federal de Ouro Preto (UFOP), Professor at Newton Paiva University Center, Minas Gerais, Brazil.

(iD) https://orcid.org/0000-0002-4846-5291

$\triangle$ rodrigopinheiro506@gmail.com

Milton Rosa

Doctorate in Education - Educational Leadership, from California State University (CSUS), Professor of the Professional Master Degree in Mathematics Education, Minas Gerais, Brazil.

http://orcid.org/0000-0002-5190-3862 $\triangle$ milton.rosa@ufop.edu.br

Received in 01/09/2019 Accepted in 05/12/2019 Published in 04/03/2020

Resumen: Los resultados obtenidos de la investigación acerca de los rasgos culturales producidos por los estudiantes Sordos en relación con el desarrollo de su educación financiera están de acuerdo con la perspectiva del Programa de Etnomatemática. En este artículo, los autores presentan el perfil de los participantes y proporcionan una breve descripción de la teoría fundamentada que forma el diseño metodológico utilizado para llevar a cabo este estudio mediante el uso de procedimientos de codificación específicos. Los autores también enfatizan la relación entre la etnomatemática y la cultura de los sordos a través del uso de su lenguaje y los procedimientos utilizados por los estudiantes sordos en el estudio de contenidos matemáticos relacionados con la educación financiera. También presentamos una diversidad de formas de señalar el mismo contenido matemático en Lengua de Signos Brasileña (Libras), así cómo las diferencias comunicativas que surgen debido a la variación de estas señales. Los resultados obtenidos en este estudio muestran que las etnomatemáticas contribuyeron a la comprensión y conocimiento de las características de la Cultura Sorda y sus relaciones con las matemáticas escolares. Otra contribución es que la etnomatemática y su acción pedagógica adquirieron un estatus relevante en la elaboración de un currículo matemático y en el desarrollo de la educación financiera para estudiantes Sordos.

Palabras clave: Estudiantes Sordos. Cultura Sorda. Etnomatemáticas. Libras. Educación Financiera.

\section{Caminhos etnomatemáticos para a Educação Financeira: analisando traços culturais de estudantes Surdos}

Resumo: Os resultados obtidos nessa pesquisa sobre os traços culturais produzidos por alunos Surdos no desenvolvimento de sua Educação Financeira estão de acordo com a perspectiva do Programa de 
Etnomatemática. Nesse artigo, os autores descrevem o perfil dos participantes e apresentam uma breve descrição da Teoria Fundamentada nos Dados, que foi o design metodológico utilizado para conduzir esse estudo por meio de procedimentos específicos de codificação. Os autores também enfatizaram a relação entre a Etnomatemática e a Cultura Surda através do emprego de jargões e procedimentos utilizados por estudantes Surdos no estudo de conteúdos matemáticos relacionados à Educação Financeira. São apresentadas, também, distintas maneiras de sinalizar o mesmo conteúdo matemático na Língua Brasileira de Sinais (Libras), bem como as diferenças comunicativas que surgem devido à variação desses sinais. Os resultados obtidos nesse estudo mostram que a Etnomatemática contribuiu para a compreensão e conscientização das características da Cultura Surda e as suas relações com a matemática escolar. Ademais, salienta-se que a Etnomatemática e a sua ação pedagógica adquiriram um status relevante na elaboração de um currículo matemático e no desenvolvimento da Educação Financeira para alunos Surdos.

Palavras-chave: Alunos Surdos. Cultura Surda. Etnomatemática. Libras. Educação Financeira.

\section{Inicial Considerations}

Deaf education in Brazil has been widely discussed and studied by numerous researchers (PERLIN, 2002; QUADROS \& PERLIN, 2007; SKLIAR, 2004; STROBEL, 2008), culminating in various works about: a) Libras' (Brazilian Sign Language) linguistic issues, b) translating procedures and interpretation from Libras to Portuguese and vice versa, $c$ ) teaching Portuguese as a second language to Deaf people, d) Deaf children's language acquisition and e) literacy and lettering issues in Deaf people's education. However, Pinheiro (2017) states that investigations related to mathematics education for Deaf people in Brazil can be considered both recent and also scarce, mainly when its involvement and connection with recent tendencies are searched as, for example, the ethnomathematics of the Deaf Culture.

On the other hand, the history of education for deaf people, the current laws and the completed research show that deaf people have many specific traits and also participate in a specific cultural group. The Deaf people in Brazil have their own language (Libras) and a different worldview from that of the hearing people (PINHEIRO, 2017). These social, linguistic, cultural and historical characteristics constitute Deaf Culture. Deaf people are considered different because they have their own way of learning and understanding the world differently from the listener way being that deafness is a cultural difference that has its own gestural and visual language (PINHEIRO \& ROSA, 2017).

In order to promote the development of Deaf students' mathematical knowledge, it is important to value both their cultural aspects and tacit knowledge1, which is developed in their own unique ways. From this point of view, Rosa (2010) argues that the ethnomathematics promotes a

\footnotetext{
1 According to Rosa \& Orey (2012), tacit knowledge is immersed in personal experience, being subjective, contextualized and analogous. This knowledge is acquired and accumulated through individual and collective living because it involves intangible factors like beliefs, perspectives, perceptions, value systems, ideas, emotions, rules, concerning, and intuitions.
} 
reflection about the teaching and learning mathematical processes according to contents and methods, and also about the role of this field of knowledge in citizenship development.

In this article, we emphasize the relation between ethnomathematics and the Deaf Culture through jargon and procedures used by deaf students when they study mathematical contents related to financial education. We will also introduce different ways of signing the same mathematical content and the communicative differences, which are the result of these signs variations.

Thus, considering that these communicative differences can undermine the overall mathematics teaching and learning process, it is important that professionals involved in this process know about sign language and Deaf Culture, because having this experience may influence how knowledge is created. The authors feel that it is possible to trace out strategies that enable Deaf students to understand and/or learn mathematical content effectively.

\section{Deaf Culture}

The deaf culture refers to the codes developed by Deaf people and their ways of organization, solidarity, language, moral judgement, and art. This is why many Deaf people in Brazil refer to themselves as participants of their own culture (SÁ, 2006).

It is important to emphasize that, like all Deaf people anywhere, Brazilian Deaf people have a own way of learning about the world that results in a certain or unique set of values, shared common behavior and social-interactive traditions. For example, Felipe (2008) stated that these own ways of apprehending the world generates values in which common behavior and sociointeractive traditions are developed and shared. This modus vivendi 2 is called deaf culture.

In this respect, the book entitled: As Imagens do Outro Sobre a Cultura Surda [The Other's Images About Deaf Culture], written by Karin Strobel, in 2008, contains a list of eight cultural artifacts 3 that show the importance of Deaf Culture and are related to the behaviors and attitudes of being Deaf, which is the unique experience of seeing, realizing and modifying the world as a Deaf person.

The first artifact, called visual experience, relates to the use of sight, in total replacement

\footnotetext{
2 Modus vivendi is a Latin expression that means mode of living or way of life, which is defined as an arrangement or na agreement that allows conflicting parties to coexist in peace (STEVENSON, 2010).

3 The artifact concept do not only refers to cultural materialism, but also to objects that, in the culture, constitute productions developed by the members of cultural groups who have their own way of being, seeing, understanding, and changing the world around them (STROBEL, 2008).
} 
to hearing, like a means of communication. Deaf Culture originates from this visual experience, being represented by the use of sign language, which facilitates the own way Deaf people have of being, and expressing themselves, knowing the world, understanding arts and acquiring scientific and academic knowledge.

In Linguistic artifact, a fundamental aspect of deaf culture is related to sign language. This artifact also includes the unique gestures common home or emerging signs from Deaf people who live in the country or isolated from deaf communities. However, sign language is the main language for Deaf people, and is expressed in spatial-visual form. In this context, Strobel (2008) affirms that sign language is the priority communication for Deaf people that is expressed in a spatial-visual mode.

In Familiar artifact, deaf relatives have their own behaviors. For example, the Deaf people usually watch TV in mute so they do not bother their neighbors. All of them prioritize the sign language at home, wash the dishes and make unexpected loud movements without noticing it.

Deaf Literature represents the memory of deaf experience from many generations and reflects several genres for example, poetry, deaf history, infant literature, the classics, fables, tales, novels, legends and other cultural manifestations. This artifact demonstrates several experiences lived by deaf people, including their struggles, difficulties and achievements related with their language and identity.

The artifact related to Sports and Social Life is important to the deaf community because it is related to sociocultural events like parties, leisure time activities, deaf community associations, weddings, baptisms and sports events all realized in sign language. For example, every four years there is the International Games for the Deaf, which brings together in sports competitions Deaf athletes from all over the world.

Politics consists in countless deaf people's movements and fights for their rights. For example, the traditional school curricula did not study the Deaf Culture, but with curricular changes, an attempt was made at introducing sign language, deaf history, and the deaf literature into these proposals.

In Visual Arts, Deaf people realize several visual artistic creations that show their emotions, their stories, their subjectivities, and their culture. There are many deaf artists who create drawings, paintings, and sculptures; which are made with beauty, balance, and harmony.

Material Artifacts are tools which help deaf people to have more accessibility in their day to day life context. For example, the Telephone Device for the Deaf (TDD) is a phone larger than 
the conventional one, which has a display in its lower part that shows the written conversation as well has a set of keys for typing.

There are also tools that use lighting like doorbells on their homes and schools, and vibrating alarm clocks. Besides that, there is accessibility for deaf people in events like, for example, in congresses and speeches where screens, posters and interpreters are used.

In this context, Pinheiro (2017) has shown that these eight cultural artifacts emphasize the main specific cultural traits ${ }^{4}$ of Deaf Culture that are related to its jargon, mathematical and scientific knowledge, and also associated to Deaf Community ideas, beliefs, language, customs, and habits.

\section{Methodological Procedures}

This article analyzes some results obtained in a Master's degree research project, from Universidade Federal de Ouro Preto (UFOP), which was conducted with 20 Deaf students, in a state school specialized in deaf education and located in the metropolitan region of Belo Horizonte. This investigation was held by a bilingual hearing teacher who is fluent in Libras and it was conducted with two groups of middle school students from the Youth and Adult Literacy Program.

Group A was formed by students from the morning shift while group B was formed by students from the night shift. Each one of these groups was composed of 10 students who communicate in Libras. In all classes, the work was communicated in Libras and was recorded and, subsequently, the raw data was translated and transcribed from it into Portuguese.

The main goal of this research, which was qualitative and based on the Grounded Theory, was related to the comprehension of the possible contributions of the ethnomathematics program to the development of financial education for Deaf students who communicate in Libras.

The qualitative data analysis was made by observing the execution of the activities blocks proposed in class. This analysis was also realized considering the data which was collected through the direct observation of the participants and noted in the first author's field diary. Besides the recordings of the classes and the three activities blocks, the researcher's field diary, 11 semi-

\footnotetext{
${ }^{4}$ Cultural trait is a system of knowledge that consists of patterns related to the traditions, meanings, beliefs, values, actions, experiences, attitudes, hierarchies, religion, notions of time, norms, roles, spatial relations, concepts of the universe, artifacts, mentifacts, sociofacts, and symbols acquired by a group of people, which are passed on from one generation to the next and are shared to varying degrees by interacting members of distinct cultural groups (TINGTOOMEY \& CHUNG, 2005). These traits identify the members of a specific culture because they can be considered like deposits of knowledge, experiences, symbology, livings, actions, cosmology, artifacts, attitudes, hierarchy, religion, senses of time, spacious and time relations, and also universe concepts and different views of the world developed by members of distinct cultural groups, which are widespread from generation to generation (SAMOVAR et al., 2000).
} 
structured interviews, and two questionnaires (one initial and other one final) were also utilized.

According to the assumptions of the Grounded Theory (GLASER \& STRAUSS, 1967), the set of raw data, called theoretical sampling, was collected during the conduction of the fieldwork and transcribed to make its analysis easier, and also to enable the interpretation of results obtained during the development of the analytical phase of this study.

Subsequently, data was then coded through open coding to determine the preliminary codes5. After, these codes were grouped into conceptual categories according to their similarities through axial coding. The main goal of this categorization was to facilitate interpretation of the results while searching the answer to the investigation question.

\section{Analyzing and interpreting about ethnomatematical registers}

During the gathering of raw data, the jargon, techniques, and strategies used by Deaf students, which are specific from the Deaf Culture, were observed, and are considered as ethnomathematical registers from the members of this distinct cultural group. It is important to use the sign language ethnomathematical registers because they can contribute to the teaching and learning process of mathematical content in the classroom.

According to Rosa (2010), ethnomathematical registers' main goal is to inventory, safeguard, conserve, and preserve the creation processes, maintenance and transmission of ideas, mathematical practices related to cultural manifestations, and the identities and memories of members from distinct groups through registering knowledge and performing, as well as the different forms of expression and communication of mathematical knowledge.

In this way, we selected an episode from the data analysis and the interpretation of the results obtained in this study, relating to a class about the monetary system, in which a participant used a specific strategy from the Deaf Culture members to solve a certain situation/problem. This episode occurred due to curiosity by some participants in the study about money addition and, then, the researcher proposed the following situation/problem: If I have four coins equivalent to 25 cents, how much do I have in total?

The analysis of the given answers to this question shows that 3 (three) participants of the

\footnotetext{
5 It is worth mentioning here that, to ensure the confidentiality of the participants IDs, numbers adjacent to the letters $A$ and $B$, which mean the two students group, were used to identify students from both groups like, for example, $A 1$, $A 2, \ldots, A 20$ or $B 1, B 2, \ldots, B 21$. Thus, the participants with even numbers represented female gender while the participants with odd numbers represented male gender.
} 
group A answered, immediately, that the answer is one real, while 4 (four) participants did not answer the question. However, participant $A 7$ asked to the first author if he could explain to the other participants the procedure which he had used to solve the question.

The images represented in Figures 1, 2, 3, and 4 show the reproduction of the participant A7 who explained his own way (ethnomathematical jargon) to solve the question developed in the classroom. We emphasize that this sequence of figures are being shown this way because of the difficulty in transcribing participant $A 7$ movements, which were performed in Libras.

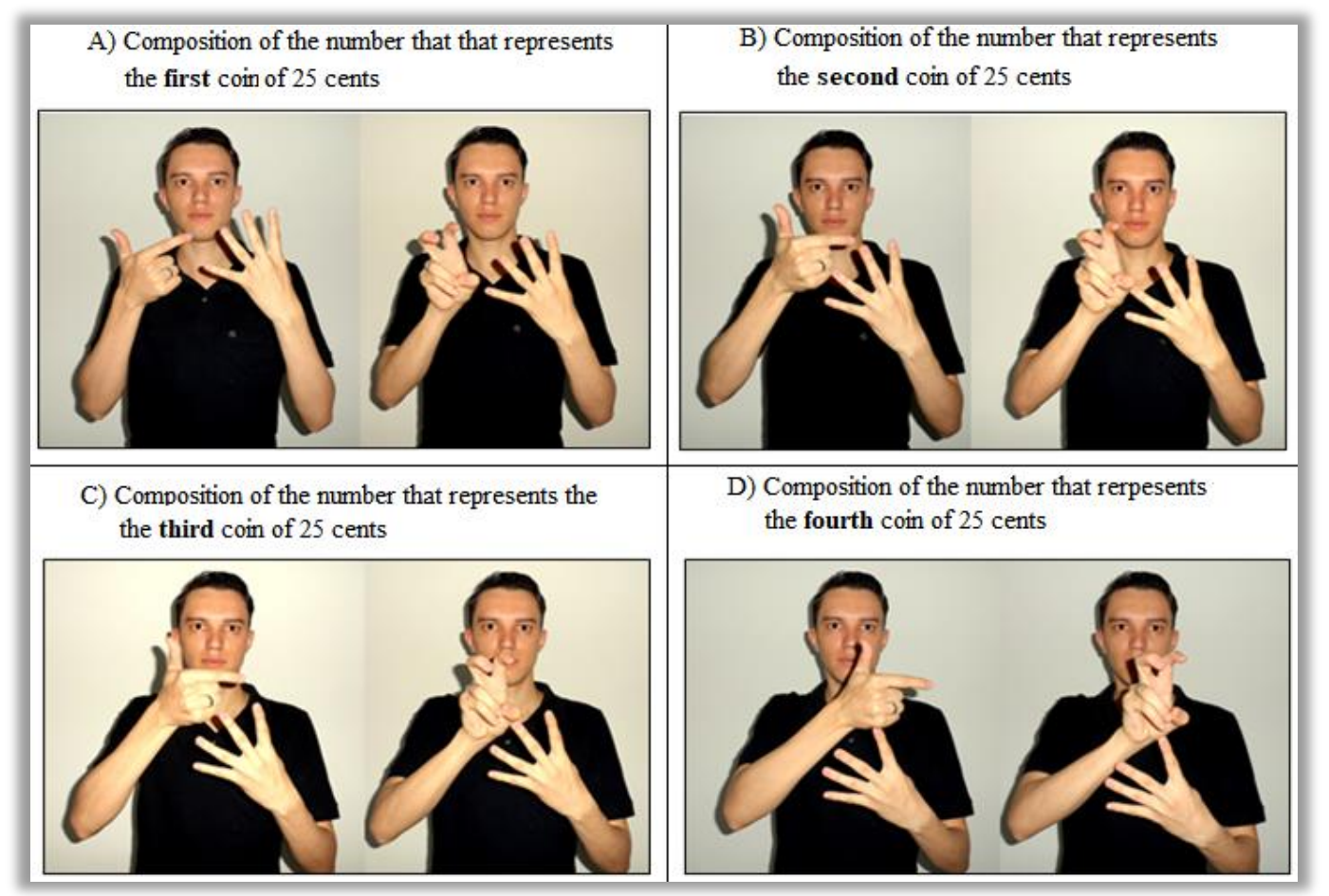

Figure 1: Representation of the four coins of 25 cents in Libras (First author's personal file)

In image A, in Figure 1, represent the numbers 2 and 5, respectively. This image expresses the number 25, in Libras, which is formed next to the little finger, indicating the first 25 cents coin. In image $B$, in Figure 1, the photographs represent the numbers 2 and 5, respectively. This image expresses the number 25, in Libras, which is formed next to the ring finger, indicating the first 25 cents coin. Similarly, image $\mathrm{C}$ represents the third 25 cents coin, which was signalized next to the middle finger, while image $D$ represent the fourth 25 cents coin and was signalized next to the index finger. 


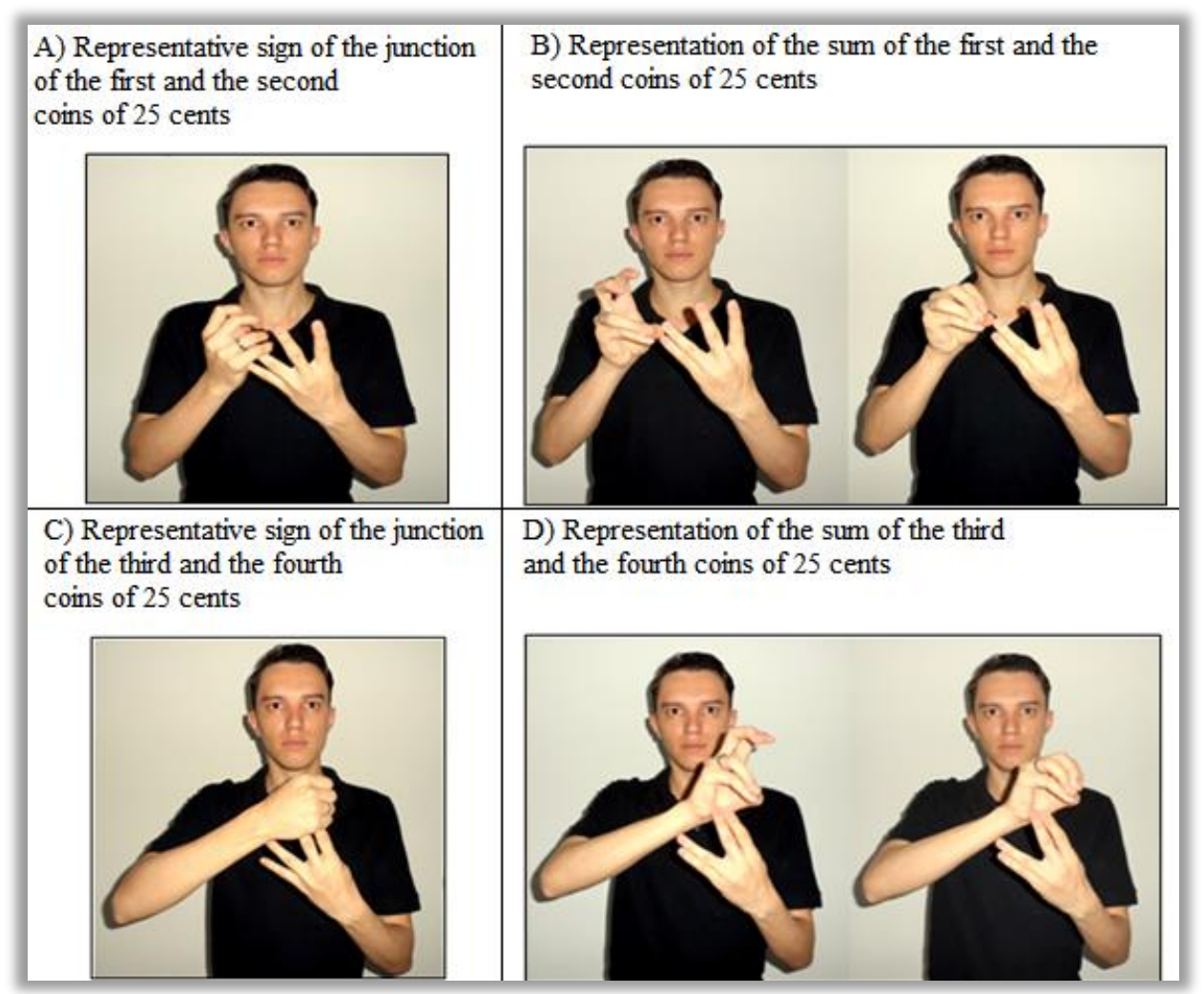

Figure 2: Representation of the four coins of 25 cents together (First author's personal file)

Image A, in Figure 2, indicates the first and second coins of 25 cents together, which were represented by the little and ring fingers. The photographs in image B, in Figure 2, represent numbers 5 and 0 , respectively, which correspond to number 50 in Libras so; the join of the two first coins of 25 cents equals 50 cents. Image $C$, in Figure 2 , indicates the third and fourth coins of 25 cents together, which were represented by the middle and index fingers. Image $D$, in Figure 2, represent numbers 5 and 0 , respectively, which correspond to number 50 in Libras; in other words, the join of the two last coins of 25 cents equals 50 cents.

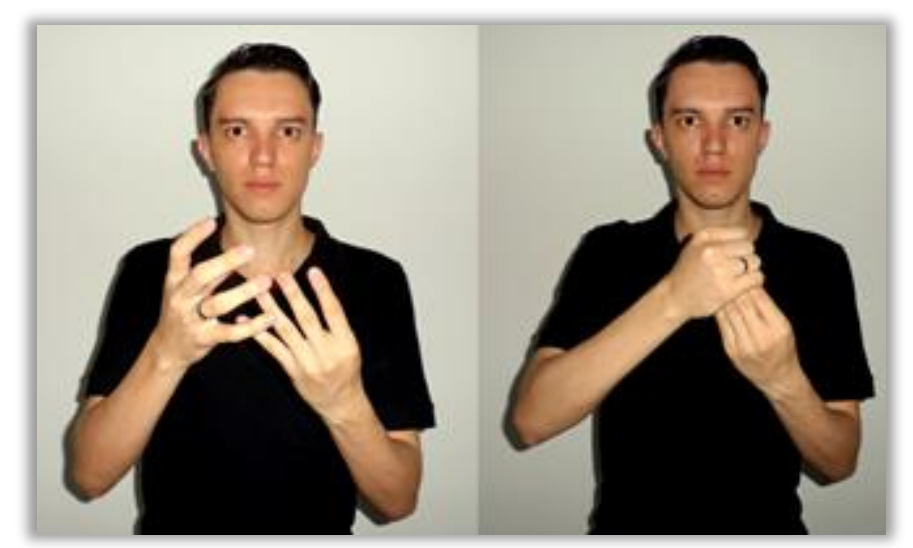

Figure 3: Representation of the sum of the four coins of 25 cents (First author's personal file)

The two images represented in Figure 3 show the join of all fingers, in other words, the sum of the four coins. 


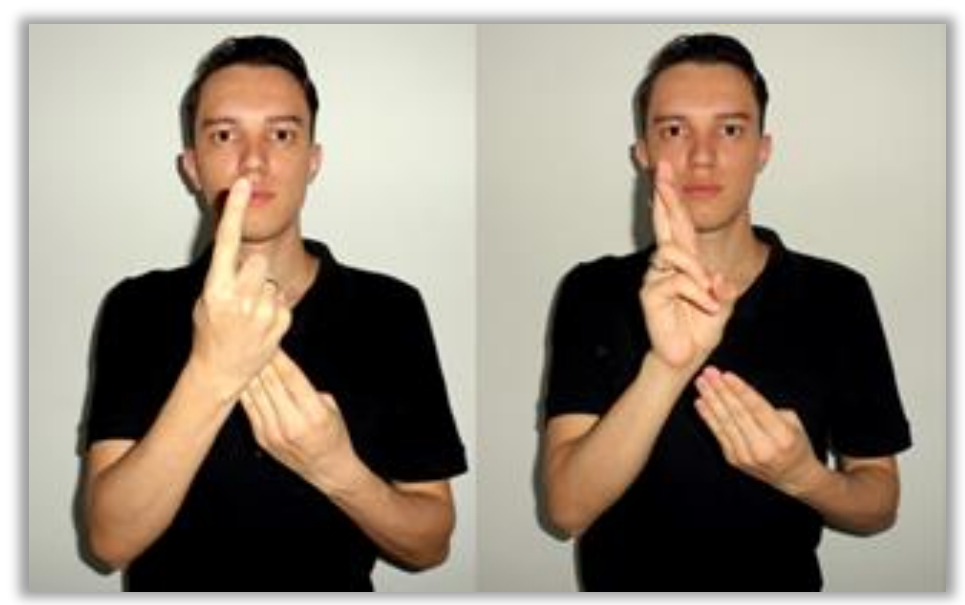

Figure 4: Representation of 1 (one) real (First author's personal file)

The representation of the two images in Figure 4 shows that the joining of all fingers, in other words, the sum of the four coins, equals one real, considering that the first image indicates the number 1 and the second image represents the word real.

Therefore, it is important to emphasize that the explanation of participant $A 7$, utilizing his own jargon, enabling other participants opportunity to understand the situation/problem given. It is also necessary to emphasize that the explanation developed by the first author was not enough for the majority of the participants to understand the solution of the proposed problem because this professional did not utilize strategies of resolution that are particular from the Deaf Culture.

Another episode that we highlight from the research made was related to a questioning that emerged during the data analysis process relating to the $\operatorname{sign}^{6}$ of equal ${ }^{7}$. Then, to eliminate this doubt, the first author returned to the work field to interview some participants again. It is important to emphasize that the plus sign is an operational symbol which indicates an action to be performed with the numbers which were proposed in the activities. However, the equal is a relational symbol because there is no associated action with this representation.

In this way, Pinheiro (2017) argues that, instead of indicating an operation, equality describes a relation of equivalence between two number expressions, however, this relation cannot be considered as a result of a determined action. Consequently, it is important that teachers help both deaf and/or hearing students to expand the concept of equality so they can understand that

\footnotetext{
${ }^{6}$ This research did not have as a goal the further development of linguistic discussions originated from the images represented in this article, which can come up with questions relating to the status of sign, classifier or gestures on this figures representations. However, it is important to emphasize that utilizing the term sign/Sign on the images titles and in the body of the text, even though existing some disagreement between some Linguistic theorists relating to its utilization, was kept for a matter of standardizing, therefore, this understanding can be considered enough to the development of this research.

${ }^{7}$ This term in Portuguese is available in: http://conceito.de/iqualdade\#ixzz4RF0dBAnx. Accessed on August 28th 2018.
} 
the equality sign is an indicator of equivalence and not only a symbol which means that the answer has to be given to any Math operation given.

This way, 5 (five) participants were randomly chosen, 3 (three) from group A and 2 (two) from group $B$, to the realization of signing in Libras in some mathematics operations, which had the equal (=) sign in different contexts like, for example, on basic operations, on equations and number expressions, and also to compare if two number are different or the same. For example, table 1 shows operations which were proposed to analyze the signs utilized by the participants. We emphasize that the operations of the table 01 were in front of the participants while they realized the Libras signaling.

Table 1: Mathematical operations proposed to Deaf students so they could show the resolution in Libras

\begin{tabular}{|c|c|}
\hline \multicolumn{2}{|c|}{ Mathematical Operations } \\
\hline (Addition operation) & (Numerical expression) \\
$2+2=4$ & $(3+5)-2=?$ \\
& $8-2=6$ \\
\hline & (Equation) \\
(Multiplication operation) & $3 \times+4=10$ \\
$7 \times 3=21$ & $3 x=10-4$ \\
& $3 \times=6$ \\
& $X=6 / 3$ \\
& $X=2$ \\
\hline (Division operation) & 23 \\
$10 \div 2=5$ & +10 \\
\hline & (Mounted addition operation) \\
& 33 \\
(Subtraction operation) & (Comparison between two numbers) \\
$5-2=3$ & $2=4$ \\
& $2 ? 3$ \\
& $10=10$ \\
\hline
\end{tabular}

Source: First author's personal file

It is important to emphasize that, in Portuguese, the word equality has various meanings and it is derived from the word equal, from the Latin term aequalitas, which means the correspondence and the proportion resulted from many parts that form a uniform whole. This term allows us to designate the consistency between two objects, in means of form, quantity, quality or nature.

However, mathematically speaking, an equality is typified when two operations or quantities are equal, in other words, when the two operations have the same number of units. This characteristic is valid for all arithmetic operations. For example, $2+4+9=15$ is an equality $15=$ 
15 because the parts on the left and on the right side of the equals sign $(=)$ has exactly the same number of units.

According to Ferreira (2000), the term equality means the quality or status of equal, considering, mathematically, that it means the expression of a relation between equal mathematical elements. Similarly, the word equal can be considered as an expression that has the same: appearance, structure or proportion (identical); level or plan; quantity, value, quantity, amount or number (equivalent), and condition, category, or nature (FERREIRA, 2000).

As well as in Portuguese, the word equality or equal sign can be used in different contexts in Libras because the sign utilized to represent equality can also vary according to the context where it is being used. This discussion relates to the Deaf Culture context because, according to D'Ambrosio (1998), it includes considerations such as language, jargons, codes of behavior, myths and symbols; mathema, which means to explain, to know, to understand; and tics that comes from techné, which is the same root of art and technique. Hence, ethnomathematics is the art or technique of explaining, of knowing, of understanding in different cultural contexts.

The interpretation of the data analysis shows that these participants utilize distinct signs to represent equality but, the utilization of these signs varied according to the Deaf students understanding and to the type of operation they were doing. Thus, to represent equality in a simple Math operation like, for example, addition, subtraction, multiplication and division, the participants $A 1, A 13$ and $B 23$ utilized the sign presented by the first author in Figure 5.

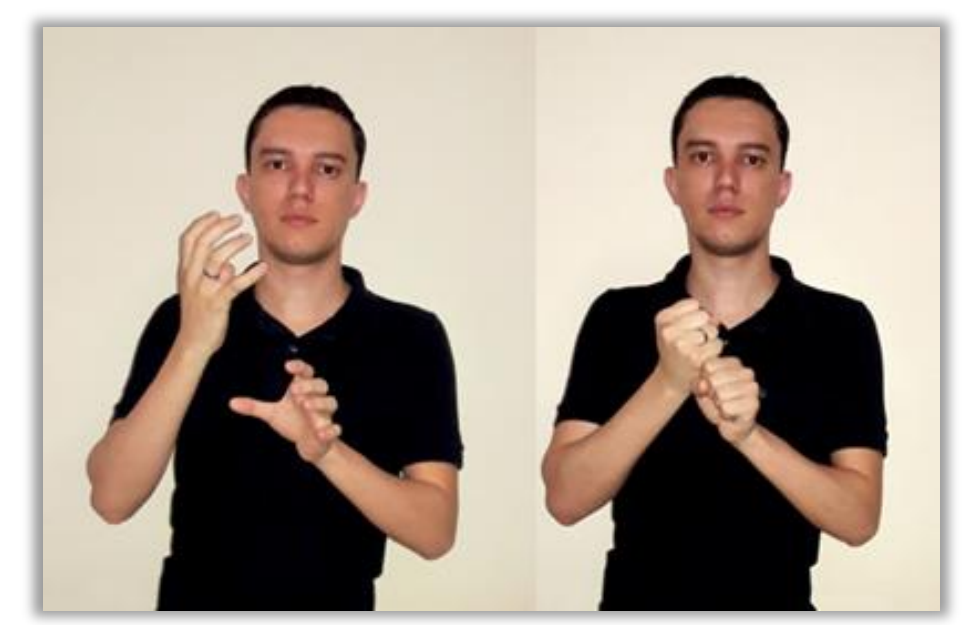

Figure 5: Sign utilized by participants $A 1, A 13$ and $B 23$ to represent equality in a simple Math operation (First author's personal file)

On the other side, to represent equality in a numerical expression, in an equation or in a comparison between two numbers, the participant B23 utilize the sign depicted in Figure 5 while the participants $A 1$ and $A 13$ utilized the sign represented in Figure 6. 


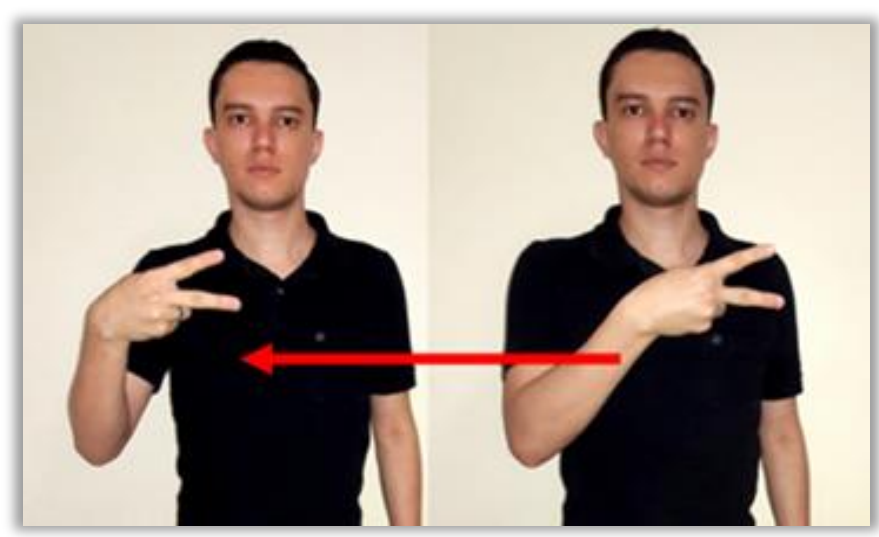

Figure 6: Sign utilized by participant B23 to represent equality in an equation, numerical expression or in a comparison between two numbers (First author's personal file)

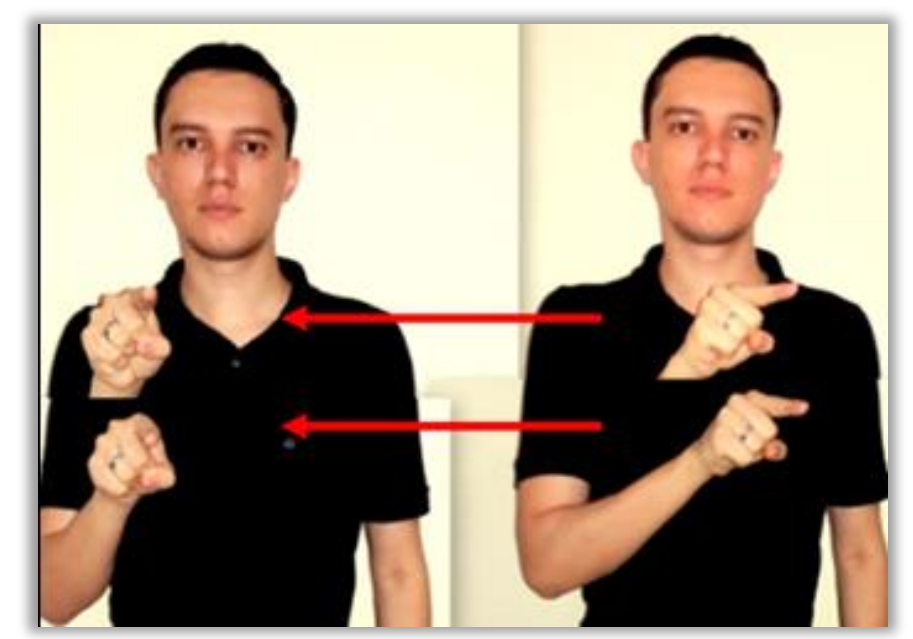

Figure 7: Sign utilized by participants A1 and A13 to represent equality in an equation, numerical expression or in a comparison between two numbers (First author's personal file)

When questioned about the reason of the sign change to represent equality, the participant B23 commented that "By the time to make the calculations I use this sign [Figure 5] because I am calculating, I think the fourth grade teacher who taught me that. This sign [Figure 6] I used because I was just showing the numbers, I was not calculating, so I utilized a classifier".

Participants $A 2$ and $B 27$ utilized the same strategy, shown in Figure 7, to represent the equality sign in almost all the operations they used and, sometimes, they just pointed towards the result, without using the equality sign. According to participant B27, "with this sign [Figure 7] is easier to understand all the calculations".

However, participant $A 5$ utilized the sign represented in Figure 8 when checking if two numbers are equal but, on the other operations, this participant did not use this sign to represent equality because he preferred to point towards the obtained result. 


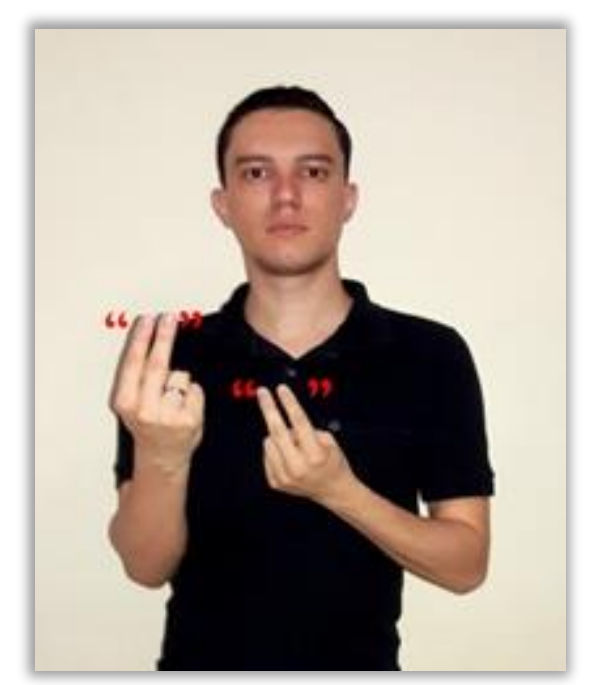

Figure 8: Sign utilized by participant $A 5$ to indicate that two numbers are equal (First author's personal file)

It is worth pointing out that the sum is the result from the addition of two or more parcels. Then, if students make $2+3=5$, this operation is interpreted like the sum of 2 and 3 whose result is 5 and, therefore, it is possible to infer that some participants utilized this symbology, which means total, sum or calculate, on the proposed activities.

On the other hand, if participants work with the expression 5 equals 5 , the signs represented in Figures 5, 6 and 7 can be used because the quantities from both sides are equal. However, equality can also be represented by the term is but, the participants did not utilize this symbology because it is not incorporated in their vocabulary. However, some teachers of Deaf students utilize the term is to indicate equality in mathematics operations.

It is necessary to emphasize the different ways of signing are not necessarily considered as barriers to the communication of Deaf students. In this case, these differences are ways in which language operates that can contribute to the understanding of concepts related to the mathematical content developed in the schools (PINHEIRO, 2017).

This episode shows that ethnomathematics can be understood as a research program which has a mediator role between the knowledge developed in many sociocultural contexts and also in school environments. Thus, this program can be defined as mathematics found among identifiable cultural groups, such as national tribal societies, worker groups, children of a certain age, professional class, etc. Their identity largely depends on the focus of interest, motivation, and certain codes and jargon that do not belong to the domain of academic mathematics (D'AMBROSIO, 1994).

In accordance with this context, Deaf people can be considered as an identifiable, 
community, and as a plural sociocultural group which has its own language and develops and uses jargon, techniques and strategies, that may be different from those used in schools. In this sense, Rosa (2010) argues that these ethnomathematical registers can be considered as cultural traits utilized by members of different cultural groups.

Consequently, in order for Deaf students to evolve academically and intellectually, it is important that their language and culture are respected. In this way, it is necessary that Deaf people, through their visual space language, utilize their own cultural and linguistic systems so they can build mathematical meanings to share in their own cultural group and also in other communities.

Therefore, through Brazilian Sign Language (Libras), it is possible for Deaf students consolidate their communication process so they can express and share, with other cultural group members, the complex or abstract mathematical contents which are addressed in class and in their daily life (PINHEIRO, 2017). The traditional practice of teaching and learning process promotes the procedural aspect of mathematical knowledge, which demands the development of the students' interpretation ability. This ability, which is linked to oral language domain, becomes a barrier to Deaf students' mathematical learning.

Consequently, one of the obstacles for the triggering of this learning is the nature of the Mathematics formalization because there is a tendency of developing a premature formalization of this discipline teaching contents. Then, Pinheiro (2017) argues that one alternative to overcoming this obstacle is to present a less formal mathematical language looking for, however, a way of making the formalization process accessible to Deaf students.

Therefore, it is necessary that the teachers: a) facilitate the recognition of the mathematical characteristics and properties of their contents, b) highlight their mathematical contributions in other knowledge fields, and c) promote social interaction, cooperation, collaboration and interactivity (PINHEIRO, 2017). Hence, it is also important to emphasize that these factors contribute to the pedagogical actions planning that enable the development of observation, transformation, representation, and communication, and also the elaboration of many mathematical concepts.

\section{Final Considerations}

Deaf students enter schools with different mathematical tools to classify, measure, organize, quantify, infer and model because they act according to the environment resources where they are in. So that these students can exercise citizenship, there is the need for the viabilization 
of a school environment which enables the systematization of knowledge and dos developed in their own cultural environment.

The experience with the activities developed in class conducted by the researchers proposed a different manner of putting mathematics in service of Deaf students that enables them to develop their autonomy and citizenship through using the an ethnomathematics perspective as pedagogical action.

This perspective which was used to develop curricular activities elaborated with financial mathematical concepts enabled and found in ethnomathematics an answer to diminish concerns about the education process for Deaf students. Thus, ethnomathematics can be considered as a research program in the History of Mathematics and Philosophy with obvious pedagogical implications (D’AMBROSIO, 2009).

Considering that the learning and teaching process in mathematics must be adapted to the Deaf students' social, historical, and cultural contexts, it is necessary to emphasize that this knowledge is an important condition to these critical and reflexive actions in society. It is important that the educational system continues to develop and provide access to useful mathematical tools and the knowledge of the existence of these students and also to better understand diverse situations problems for all.

Seen in this way, there is the need of teachers' constant attention to Deaf student interests and needs and include their jargon, procedures, techniques, and strategies of problem resolution, so they can better learn mathematical practices to succeed in their classes. In this context, the results obtained in the study conducted by Pinheiro (2017) have shown that an important contribution of the ethnomathematics program in the development of financial education of Deaf students who communicate in Brazilian Sign Language (Libras) was to show respect and attention to their culture and also to their daily experiences.

These results also show the relevance of the ethnomathematical perspective to the promotion of significant relations between day-to-day knowledge with mathematical knowledge systematized by the school, since the methodology adopted in this study was related to the contextualization of everyday facts through which it was possible to negotiate meanings in the classroom, thus, favoring the construction of mathematical and financial concepts by Deaf students.

It is relevant to expand the debate about the ways in which ethnomathematics contributes to the development of pedagogical action in bringing educational proposals closer to Deaf student realities. With that in mind, the aim of this approach was to help teachers to promote an education 
which values cultural diversity and also enables the integration and access for Deaf students' academic knowledge.

There is a need for pedagogical action that values the cultural context of Deaf students whose activities can be elaborated by using elements from their own reality, and also to identify mathematical procedures they must consider in solving problems that help them to read their own world (MONTEIRO \& POMPEU JR., 2001).

Thus, understanding Deaf students' mathematical knowledge is an important tool of empowerment and respect of their own cultural differences. The ethnomathematical perspective was used in this study in the elaboration of proposed activities in class to enable the learning of mathematical content through the interpretation and verbalization of this knowledge by using the sign language.

Because this program focused on contextualizing daily mathematical practices in class, the ethnomathematics importance was emphasized through the proposition of a pedagogical action in which Libras and Deaf Culture acquires a central relevance to mathematical curriculum, including to hearing students.

Seen in these terms, ethnomathematics certainly contributes to the understanding and awareness of deaf cultural characteristics and its relations to school mathematics. Thus, the strategies performed with hands were used to represent the coins addition without, necessarily, utilize the addition and sum signs. These are examples of ethnomathematical registers. Another situation that exemplified the use of deaf registers was the utilization of classifiers to represent equality.

These classifiers, in particular, are manipulated to specify locations, arrangements, manners, directions, and movement rates and they can reflect, for example, the path and the way where a person, animal or object moves from a place to another; jumping, swinging, meandering, stumbling, twisting in and out, rolling and moving up, down or transversally (KLIMA \& BELLUGI, 1979, p.13-15).

Thus, the use of ethnomathematics in class showed that it is possible to exercise a way of thinking, know and do mathematics, developed in Deaf Culture, which differ from the hearer perspective, through using a teaching and learning process based on resolution of curricular 
activities which were also visual8.

As well, the awareness for the potentiality in Libras/sign language in the process of financial education development was also an important ethnomathematics contribution because the researcher used a distinct pedagogical methodology to meet the educational needs of his participants in order to work with differences in the classrooms (MANTOAN, 2009).

Therefore, the researchers have shown a strong connection between ethnomathematics and Deaf Culture. The assumptions of this program help teachers to recognize the sign language as one of the main elements of identification in this culture; Libras can be considered a mediator in the teaching and learning process of different mathematical thoughts.

An ethnomathematics program enables the overcoming of communication differences and can contribute to, and can provide opportunities to Deaf students to transcend and evolve their mathematical potential (PINHEIRO, 2017). Finally, it is important that schools and educational institutions provide pedagogical practices that enable Deaf students to access their own culture, jargons and techniques so that they may address the many demands, and exchanges they face between their daily experiences and that of the school environment.

\section{References}

D'AMBROSIO, Ubiratan. Ação pedagógica e Etnomatemática como marcos conceituais para 0 ensino de Matemática. In: BICUDO, Maria Aparecida Viggiani (Org.). Educação Matemática. São Paulo: Moraes, 1994, p. 73-100.

D'AMBROSIO, Ubiratan. Etnomatemática - elo entre as tradições e a modernidade. Belo Horizonte: Autêntica, 2009.

D'AMBROSIO, Ubiratan. Etnomatemática: arte ou técnica de explicar e conhecer. São Paulo: Ática, 1998.

FELIPE, Tanya Amara. LIBRAS em contexto: curso básico. Livro do estudante. Brasília: Ministério da Educação / Secretaria de Educação Especial, 2008.

FERREIRA, Aurelio Buarque de Holanda. Miniaurélio Século XXI Escolar: o minidicionário da língua portuguesa. Rio de Janeiro: Nova Fronteira, 2000.

\footnotetext{
8 Please check the analysis developed by Pinheiro (2017), topic 3.1.2.1.1., in relation to the raw data collected in classroom about currency and the Brazilian currency history system. Available in https://www.repositorio.ufop.br/handle/123456789/7765.
} 
GLASER, Barney G.; STRAUSS, Anselm L. The discovery of grounded theory: strategies for qualitative research. Chicago: Aldine, 1967.

KLIMA, Edward S.; BELLUGI, Ursula. The signs of language. Cambridge: Harvard Universiy Press, 1979.

MANTOAN, Maria Teresa Eglér. Entrevista: Inclusão promove a justiça. Revista Nova Escola Online. São Paulo: Abril, 2009.

MONTEIRO, Alexandrina; POMPEU JR., Geraldo. A Matemática e os temas transversais. São Paulo: Moderna, 2001.

PERLIN, Gladis Teresinha Taschetto. História dos Surdos. Florianópolis: UDESC/CEAD, 2002.

PINHEIRO, Rodrigo Carlos. Contribuições do Programa Etnomatemática para o desenvolvimento da Educação Financeira de alunos Surdos que se comunicam em Libras. 2017. 284f. Dissertação (Mestrado em Educação Matemática) - Departamento de Educação Matemática. Universidade Federal de Ouro Preto. Ouro Preto.

PINHEIRO, Rodrigo Carlos; ROSA, Milton. O Programa Etnomatemática como uma ação pedagógica para o desenvolvimento da Educação Financeira de alunos surdos que se comunicam em Libras. Revista Latinoamericana de Etnomatemática, v. 10, n. 3, p. 181-200, 2017.

QUADROS, Ronice Müller; PERLIN, Gladis Teresinha Taschetto. Estudos Surdos II. Petrópolis: Arara Azul, 2007.

ROSA, Milton. A mixed-methods study to understand the perceptions of high school leaders about English Language Learners (ELL) students: the case of Mathematics. 2010. 583f. Dissertation (Doctorate of Education) - College of Education. California State University. Sacramento.

ROSA, Milton; OREY, Daniel Clark. A modelagem como um ambiente de aprendizagem para a conversão do conhecimento matemático. Bolema, Rio Claro, v. 26, n. 42A, p. 261-290, abr. 2012.

SÁ, Nídia Regina Limeira. Cultura, poder e educação de surdos. Manaus: INEP, 2006.

SAMOVAR, Larry A.; PORTER, Richard E.; McDANIEL, Edwin R.; ROY, Carolyn S. (Ed.). Communication between cultures. Beijing: Foreign Language Teaching and Research Press, 2000.

SKLIAR, Carlos (Org.). Educação e exclusão: abordagens sócio antropológicas em educação especial. Porto Alegre: Mediação, 2004.

STEVENSON, Angus. Oxford dictionary of English. 3. ed. Oxford: Oxford University Press, 2010.

STROBEL, Karin. As imagens do outro sobre a cultura surda. Florianópolis. Editora UFSC, 2008.

TING-TOOMEY, Stella; CHUNG, Leeva C. Understanding intercultural communication. Los Angeles: Roxbury, 2005. 